\title{
Frequency of Use Among Middle and High School Student Tobacco Product Users — United States, 2015-2017
}

\author{
Gabriella M. Anic, $\mathrm{PhD}^{1}$; Michael D. Sawdey, $\mathrm{PhD}^{1}$; Ahmed Jamal, MBBS${ }^{2}$; Katrina F. Trivers, $\mathrm{PhD}^{2}$
}

Tobacco product use during adolescence increases the risk for lifelong nicotine addiction and immediate adverse health effects $(1,2)$. During 2011-2017, current use of cigarettes, cigars, smokeless tobacco, and pipe tobacco decreased significantly among middle and high school students, but current use of e-cigarettes increased significantly from $1.5 \%$ to $11.7 \%$ (3). In 2017 , an estimated $19.6 \%$ of high school students (2.95 million) and 5.6\% of middle school students (0.67 million) were current users of any tobacco product; e-cigarettes were the most commonly used tobacco product for both middle (3.3\%) and high (11.7\%) school students (3). The Food and Drug Administration (FDA) and CDC analyzed combined data from the 2015-2017 National Youth Tobacco Surveys (NYTS) to determine past 30-day (current) frequency of use of cigarettes, e-cigarettes, cigars, smokeless tobacco, and hookahs among U.S. high school and middle school students. During 2015-2017, the proportion of students currently using tobacco products who used a product for $\geq 20$ of the past 30 days ranged from $14.0 \%$ of cigar smokers to $38.7 \%$ of smokeless tobacco users among high school students and from $13.1 \%$ of e-cigarette users to $24.5 \%$ of hookah smokers among middle school students. Among current users, use of two or more tobacco products ranged from $76.7 \%$ (e-cigarettes) to $90.9 \%$ (hookahs) among those using the product $\geq 20$ of the preceding 30 days, from $68.0 \%$ (e-cigarettes) to $84.2 \%$ (hookahs) among those using the product for 6 to 19 of the preceding 30 days, and from $48.8 \%$ (e-cigarettes) to $77.2 \%$ (cigarettes) among those using the product for 1 to 5 of the preceding 30 days. Sustained implementation of proven tobacco control strategies focusing on all types of tobacco products, in coordination with the regulation of tobacco products by FDA, are needed to reduce tobacco product initiation and use among U.S. youths.
NYTS is a cross-sectional, school-based, pencil-and-paper survey administered to U.S. middle (grades 6-8) and high (grades 9-12) school students (4). A three-stage cluster sampling procedure was used to generate a nationally representative sample of U.S. students attending public and private schools in grades 6-12. Data were combined from the 2015 (17,711), $2016(20,675)$, and $2017(17,872)$ NYTS to provide a sufficient sample size to assess different categories of use frequency. Response rates for 2015-2017 were 63.4\%, 71.6\%, and $68.1 \%$, respectively. Information on current use ( $\geq 1$ day in the past 30 days) was collected for the following tobacco products: cigarettes, cigars (cigars, cigarillos, or little cigars), smokeless tobacco products (chewing tobacco, snuff, dip, snus, or dissolvable tobacco products), e-cigarettes, hookahs (water pipes used to smoke tobacco), pipe tobacco, and bidis (small imported cigarettes wrapped in a leaf). Information on frequency of use (number of days used in the past 30 days) was collected for

\section{INSIDE}

1358 Unresolved Splenomegaly in Recently Resettled Congolese Refugees - Multiple States, 2015-2018

1363 Low and Decreasing Prevalence and Rate of False Positive HIV Diagnosis - Chókwè District, Mozambique, 2014-2017

1369 Influenza Activity — United States, September 30-December 1, 2018

1372 Notes from the Field: Follow-Up on 11 Infants Born to Women with Evidence of Zika Virus Infection During Pregnancy — Los Angeles County, 2016

1374 QuickStats

Continuing Education examination available at https://www.cdc.gov/mmwr/cme/conted_info.html\#weekly.

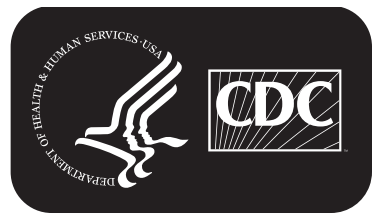

U.S. Department of Health and Human Services Centers for Disease Control and Prevention 
five tobacco products: cigarettes, cigars, smokeless tobacco, e-cigarettes, and hookahs. Frequency of hookah smoking was collected only in 2016 and 2017; the other four products were assessed in 2015, 2016, and 2017. Frequency of use information was not collected in any of the surveys for pipe tobacco, bidis, and certain specific smokeless tobacco products (snus and dissolvable tobacco products). Response options describing self-reported frequency of use were " 0 days," " $1-2$ days," "3-5 days," "6-9 days," "10-19 days," "20-29 days," and "all 30 days." Frequent use was defined as using a product for $\geq 20$ of the preceding 30 days. Multiple tobacco product use was defined as any past 30-day use of two or more tobacco products among current users of cigarettes, cigars, e-cigarettes, smokeless tobacco, and hookahs separately. Students with missing responses for frequency of use were excluded from the analysis.* Students missing data on current use of individual products were considered nonusers of that product. National prevalence estimates were calculated with $95 \%$ confidence intervals, and weighted population counts were rounded down to the nearest 10,000; all estimates were time-averaged over the pooled survey years. Survey weights were used to account for the complex survey design and adjusted for nonresponse.

During 2015-2017, among high school students who were current users of each product, the prevalence of frequent use

\footnotetext{
* The ranges of proportions of those with missing responses for frequency of use questions were $2.1 \%-2.5 \%$ for cigarettes, $1.5 \%-2.3 \%$ for e-cigarettes, $2.1 \%$ $3.1 \%$ for cigars, $1.9 \%-3.2 \%$ for smokeless tobacco products, and $2.7 \%-3.4 \%$ for hookahs.
}

( $\geq 20$ of the past 30 days) was as follows: $28.4 \%$ of cigarette smokers $(330,000), 17.4 \%$ of e-cigarette users $(330,000)$, $14.0 \%$ of cigar smokers $(160,000), 38.7 \%$ of smokeless tobacco users $(260,000)$, and $16.7 \%$ of hookah smokers $(60,000)$ (Table). Among middle school students, the prevalence of frequent use was $17.5 \%$ of cigarette smokers $(40,000), 13.1 \%$ of e-cigarette users $(60,000), 13.2 \%$ of cigar smokers $(20,000)$, $21.5 \%$ of smokeless tobacco users $(30,000)$, and $24.5 \%$ of hookah smokers $(20,000)$. High school student current users who used the product $1-5$ of the past 30 days accounted for $50.3 \%$ of cigarette smokers, $61.4 \%$ of e-cigarette users, $70.8 \%$ of cigar smokers, $45.2 \%$ of smokeless tobacco users, and $66.3 \%$ of hookah smokers. The proportion of middle school current users who used the product $1-5$ of the past 30 days was $67.4 \%$ of cigarette smokers, $68.4 \%$ of e-cigarette users, $71.2 \%$ of cigar smokers, $56.0 \%$ of smokeless tobacco users, and $61.8 \%$ of hookah users.

Among middle and high school students who used any of these five products on $\geq 20$ of the preceding 30 days, multiple tobacco products were used by $87.5 \%$ of cigarette smokers, $76.7 \%$ of e-cigarette users, $81.6 \%$ of cigar smokers, $77.0 \%$ of smokeless tobacco users, and $90.9 \%$ of hookah smokers (Figure). Similarly, for middle and high school students who currently used a product for $1-5$ of the preceding 30 days, multiple tobacco product use was reported for $77.2 \%$ of cigarette smokers, $48.8 \%$ of e-cigarette users, $72.0 \%$ of cigar smokers, $72.4 \%$ of smokeless tobacco users, and $70.5 \%$ of hookah smokers.

The MMWR series of publications is published by the Center for Surveillance, Epidemiology, and Laboratory Services, Centers for Disease Control and Prevention (CDC), U.S. Department of Health and Human Services, Atlanta, GA 30329-4027.

Suggested citation: [Author names; first three, then et al., if more than six.] [Report title]. MMWR Morb Mortal Wkly Rep 2018;67:[inclusive page numbers].

\section{Centers for Disease Control and Prevention Robert R. Redfield, MD, Director \\ Anne Schuchat, MD, Principal Deputy Director \\ Leslie Dauphin, PhD, Acting Associate Director for Science \\ Barbara Ellis, PhD, MS, Acting Director, Office of Science Quality \\ Chesley L. Richards, MD, MPH, Deputy Director for Public Health Scientific Services \\ William R. Mac Kenzie, MD, Acting Director, Center for Surveillance, Epidemiology, and Laboratory Services}

MMWR Editorial and Production Staff (Weekly)

Charlotte K. Kent, PhD, MPH, Acting Editor in Chief, Executive Editor

Jacqueline Gindler, MD, Editor

Mary Dott, MD, MPH, Online Editor

Teresa F. Rutledge, Managing Editor

Douglas W. Weatherwax, Lead Technical Writer-Editor

Glenn Damon, Soumya Dunworth, PhD, Teresa M. Hood, MS, Technical Writer-Editors

Matthew L. Boulton, MD, MPH Virginia A. Caine, MD

Katherine Lyon Daniel, PhD

Jonathan E. Fielding, MD, MPH, MBA

David W. Fleming, MD

William E. Halperin, MD, DrPH, MPH
MMWR Editorial Board Timothy F. Jones, MD, Chairman Robin Ikeda, MD, MPH Phyllis Meadows, PhD, MSN, RN Jewel Mullen, MD, MPH, MPA Jeff Niederdeppe, PhD Patricia Quinlisk, MD, MPH
Martha F. Boyd, Lead Visual Information Specialist Maureen A. Leahy, Julia C. Martinroe, Stephen R. Spriggs, Tong Yang, Visual Information Specialists

Quang M. Doan, MBA, Phyllis H. King, Terraye M. Starr, Moua Yang, Information Technology Specialists
Stephen C. Redd, MD, Patrick L. Remington, MD, MPH Carlos Roig, MS, MA William Schaffner, MD

Morgan Bobb Swanson, BS 
TABLE. Frequency of use (number of days of use during the preceding 30 days) among middle and high school students currently using cigarettes, e-cigarettes, cigars, smokeless tobacco, and hookahs* - National Youth Tobacco Survey, United States, 2015-2017

\begin{tabular}{|c|c|c|c|c|c|c|c|c|c|c|}
\hline \multirow[b]{2}{*}{$\begin{array}{l}\text { Days } \\
\text { of use }\end{array}$} & \multicolumn{2}{|c|}{ Cigarettes } & \multicolumn{2}{|c|}{ E-cigarettes } & \multicolumn{2}{|c|}{ Cigars } & \multicolumn{2}{|c|}{ Smokeless tobacco } & \multicolumn{2}{|c|}{ Hookahs $^{\dagger}$} \\
\hline & $\%(95 \% \mathrm{Cl})$ & $\begin{array}{c}\text { Estimated } \\
\text { no. of } \\
\text { users }\end{array}$ & $\%(95 \% \mathrm{Cl})$ & $\begin{array}{c}\text { Estimated } \\
\text { no. of } \\
\text { users }\end{array}$ & $\%(95 \% \mathrm{Cl})$ & $\begin{array}{l}\text { Estimated } \\
\text { no. of users }{ }^{\S}\end{array}$ & $\%(95 \% \mathrm{Cl})$ & $\begin{array}{c}\text { Estimated } \\
\text { no. of } \\
\text { users } \S\end{array}$ & $\%(95 \% \mathrm{Cl})$ & $\begin{array}{c}\text { Estimated } \\
\text { no. of } \\
\text { users }\end{array}$ \\
\hline \multicolumn{11}{|c|}{ High school } \\
\hline $1-2$ & $35.9(33.2-38.6)$ & 440,000 & $41.3(38.8-43.9)$ & 790,000 & $51.7(49.1-54.2)$ & 610,000 & $32.9(29.5-36.5)$ & 220,000 & $49.2(45.0-53.4)$ & 190,000 \\
\hline $3-5$ & $14.4(12.8-16.3)$ & 170,000 & $20.1(18.2-22.0)$ & 380,000 & $19.2(17.4-21.2)$ & 220,000 & $12.3(10.3-14.5)$ & 80,000 & $17.1(14.2-20.5)$ & 60,000 \\
\hline $6-9$ & $8.9(7.6-10.3)$ & 100,000 & $10.7(9.4-12.1)$ & 200,000 & $7.9(6.7-9.3)$ & 90,000 & $7.2(5.7-9.1)$ & 50,000 & $11.1(8.6-14.1)$ & 40,000 \\
\hline $10-19$ & $12.5(10.9-14.2)$ & 150,000 & $10.5(9.4-11.9)$ & 200,000 & $7.2(6.1-8.6)$ & 80,000 & $8.9(7.2-11.0)$ & 60,000 & $5.9(4.4-7.8)$ & 20,000 \\
\hline $20-29$ & $8.9(7.5-10.6)$ & 100,000 & $5.3(4.5-6.4)$ & 100,000 & $3.5(2.8-4.4)$ & 40,000 & $6.5(5.0-8.4)$ & 40,000 & $3.7(2.6-5.2)$ & 10,000 \\
\hline 30 & $19.4(17.1-22.0)$ & 230,000 & $12.1(10.6-13.7)$ & 230,000 & $10.5(9.0-12.3)$ & 120,000 & $32.2(27.8-37.0)$ & 220,000 & $13.0(10.1-16.6)$ & 50,000 \\
\hline \multicolumn{11}{|c|}{ Middle school } \\
\hline $1-2$ & $48.7(43.0-54.3)$ & 120,000 & $50.8(47.2-54.5)$ & 250,000 & $57.5(51.2-63.6)$ & 110,000 & $45.2(38.6-51.9)$ & 80,000 & $41.6(33.7-49.9)$ & 50,000 \\
\hline $3-5$ & $18.8(14.4-24.2)$ & 40,000 & $17.6(15.0-20.5)$ & 80,000 & $13.7(10.2-18.0)$ & 20,000 & $10.8(8.0-14.3)$ & 10,000 & $20.2(15.0-26.6)$ & 20,000 \\
\hline $6-9$ & $7.9(5.4-11.5)$ & 20,000 & $9.9(8.2-12.0)$ & 50,000 & $10.3(7.0-14.8)$ & 20,000 & $15.1(10.6-21.0)$ & 20,000 & $10.2(6.9-14.7)$ & 10,000 \\
\hline $10-19$ & $7.1(5.0-9.8)$ & 10,000 & $8.6(6.7-10.9)$ & 40,000 & $5.3(3.4-8.2)$ & 10,000 & $7.5(4.2-13.0)$ & 10,000 & -9 & - \\
\hline $20-29$ & $4.8(2.9-7.7)$ & 10,000 & $4.2(3.0-5.9)$ & 20,000 & —? & - & - & - & - & $-\pi$ \\
\hline 30 & $12.8(10.0-16.3)$ & 30,000 & $8.9(7.1-11.1)$ & 40,000 & $11.3(8.2-15.4)$ & 20,000 & $17.9(13.1-23.9)$ & 30,000 & $20.9(15.4-27.9)$ & 20,000 \\
\hline
\end{tabular}

Abbreviation: $\mathrm{Cl}=$ confidence interval.

* Frequency of current use of cigarettes, e-cigarettes, cigars (defined as cigars, cigarillos, or little cigars), smokeless tobacco (defined as chewing tobacco, snuff, or dip), and hookahs was determined by asking participants on how many days they used each of these tobacco products during the preceding 30 days. The percentages given indicate the proportion of users for each product (e.g., 35.9\% of cigarette users use that product 1-2 days per month.)

† Hookah estimates were based on data from 2016 and 2017. Frequency of hookah smoking was not asked in the 2015 survey.

$\S$ Estimated number of users was rounded down to the nearest 10,000 .

I Data are statistically unreliable because the relative standard error was $>30 \%$.

FIGURE. Percentage of middle and high school students who were current users of cigarettes, e-cigarettes, cigars, smokeless tobacco, and hookahs, who reported multiple tobacco product use, ${ }^{*}$ by number of days used during the preceding 30 days - National Youth Tobacco Survey, United States, 2015-2017

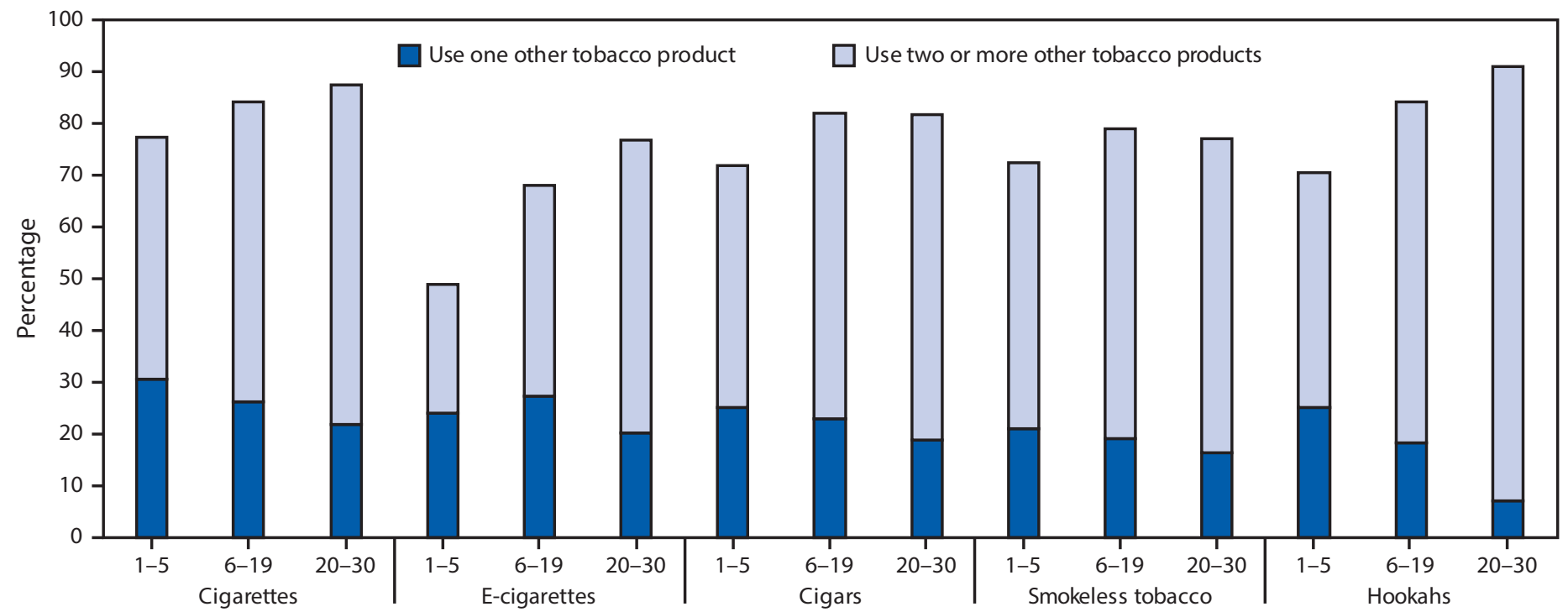

Tobacco product used and no. of days used during preceding 30 days

\footnotetext{
* Multiple tobacco product use was defined as a current cigarette smoker, e-cigarette user, cigar smoker, smokeless tobacco user, or hookah smoker also using at least one of the following products in the past 30 days: cigarettes; cigars (cigars, cigarillos, or little cigars); smokeless tobacco (chewing tobacco, snuff, or dip); e-cigarettes; hookahs; tobacco pipes; snus; dissolvable tobacco (dissolvables); and bidis.
}

\section{Discussion}

E-cigarettes were the most commonly used tobacco product by middle and high school students in 2017, followed by cigars and cigarettes (3.) Use of tobacco products in any form by youths is unsafe, including infrequent use $(1,2)$. During 2015-2017, the frequency of tobacco product use among current middle and high school users varied by product type and school level. However, for all assessed products, most current users reported using each product for $1-5$ of the past 30 days. 
The products most commonly used $\geq 20$ of the past 30 days by high school students were smokeless tobacco $(38.7 \%)$ and cigarettes $(28.4 \%)$ and by middle school students were hookahs (24.5\%) and smokesless tobacco (21.5\%).

Any frequency of tobacco product use might lead to symptoms of nicotine dependence (5). Symptoms of dependence, including strong cravings (14\%), irritability and restlessness when not using tobacco products $(11 \%)$, strong desire to use the product $(6 \%)$, and wanting to use the tobacco product within 30 minutes of awakening (1\%) have been reported by U.S. adolescent tobacco product users who use a single tobacco product on 1-2 of the previous 30 days (5). A high prevalence of multiple tobacco product use was observed for all products, regardless of the number of days that a tobacco product was used. The prevalence of reporting symptoms of nicotine dependence is $2-3$ times higher for multiple product users than that for single product users (5). Given that nicotine dependence is a major determinant of whether a person becomes a long-term user of tobacco products, reducing experimentation by youths and initiation of all forms of tobacco product use is important to preventing future dependency on, and more frequent use of, these products $(1,2,6)$.

The findings in this report are subject to at least four limitations. First, the data are self-reported; thus, the findings are subject to potential reporting bias. Second, data were not collected on the frequency of using tobacco pipes, snus, dissolvables, bidis, or by type of cigar. Although this precludes reporting frequency of use for these specific products, it should not affect the reported estimates of frequency of use of cigarettes, cigars, e-cigarettes, smokeless tobacco, and hookahs. Third, data were averaged across several years, although there were no significant changes in frequency of use during 2015-2017 for most products. ${ }^{\dagger}$ Finally, NYTS only recruited students from public and private schools; therefore, the findings might not be generalizable to youths who are being home-schooled, have dropped out of school, or are in detention centers.

Understanding tobacco product use patterns, including frequency of use and multiple tobacco product use, is important for sustaining implementation of proven tobacco control strategies and regulation of all types of tobacco products. In 2009, FDA was granted immediate authority to regulate cigarettes, cigarette tobacco, roll-your-own tobacco, and smokeless tobacco $\$$; in 2016, FDA issued a final rule that extended its regulatory authority to all other tobacco products (7). Regulation

\footnotetext{
${ }^{\dagger}$ A chi-squared test found no significant differences across years for the prevalence of infrequent, moderate, and frequent use of e-cigarettes $(\mathrm{p}=0.11)$; cigars $(\mathrm{p}=$ $0.44)$; smokeless tobacco products $(p=0.66)$; and hookahs $(p=0.80)$. The prevalence of frequent cigarette smoking decreased during 2015-2017 ( $\mathrm{p}=0.01)$.

$\$$ Family Smoking Prevention and Tobacco Control Act, Pub. L. 111-31, 123 Stat. 1776 (June 22, 2009). https://www.gpo.gov/fdsys/pkg/PLAW-111 publ31/pdf/ PLAW-111publ31.pdf.
}

\section{Summary}

What is already known about this topic?

Most tobacco product use begins during adolescence or young adulthood, increasing the risk for lifelong nicotine addiction and adverse health effects.

What is added by this report?

During 2015-2017, the proportion of students currently using cigarettes, cigars, e-cigarettes, smokeless tobacco, or hookahs who used each product $\geq 20$ of the past 30 days ranged from $14.0 \%$ of cigar smokers to $38.7 \%$ of smokeless tobacco users among high school students and from $13.1 \%$ of e-cigarette users to $24.5 \%$ of hookah smokers among middle school students.

What are the implications for public health practice?

Understanding tobacco product use patterns including frequency of use is important for sustained implementation of proven tobacco control strategies and the regulation of tobacco products.

of tobacco products, along with implementing proven tobacco control and prevention strategies, can reduce the initiation and use of tobacco products among youths. Strategies to reduce youth tobacco product use include increasing the price of tobacco products, implementing advertising and promotion restrictions and national public education media campaigns, and raising the minimum age of purchase for tobacco products to 21 years $(1,2,8,9)$. Monitoring the frequency of using tobacco products, including the use of multiple products, is important for informing these strategies to prevent and reduce youth tobacco product use.

Corresponding author: Gabriella Anic, gabriella.anic@fda.hhs.gov, 240-402-6941.

${ }^{1}$ Office of Science, Center for Tobacco Products, Food and Drug Administration, Beltsville, Maryland; ${ }^{2}$ Office on Smoking and Health, National Center for Chronic Disease Prevention and Health Promotion, CDC.

All authors have completed and submitted the ICMJE form for disclosure of potential conflicts of interest. No potential conflicts of interest were disclosed.

\section{References}

1. US Department of Health and Human Services. Preventing tobacco use among youth and young adults: a report of the Surgeon General. Rockville, MD: US Department of Health and Human Services; 2012. https://www. ncbi.nlm.nih.gov/books/NBK99237/pdf/Bookshelf_NBK99237.pdf

2. US Department of Health and Human Services. E-cigarette use among youth and young adults. a report of the Surgeon General. Rockville, MD: US Department of Health and Human Services; 2016. https://e-cigarettes. surgeongeneral.gov/documents/2016_SGR_Full_Report_508.pdf

3. Wang TW, Gentzke A, Sharapova S, Cullen KA, Ambrose BK, Jamal A. Tobacco product use among middle and high school students-United States, 2011-2017. MMWR Morb Mortal Wkly Rep 2018;67:629-33. https://doi.org/10.15585/mmwr.mm6722a3

4. CDC. 2016 National Youth Tobacco Survey: methodology report. Atlanta, GA: US Department of Health and Human Services, CDC; 2017. https:// www.cdc.gov/tobacco/data_statistics/surveys/nyts/zip_files/2016-nytsmethodology-report.zip 
5. Apelberg BJ, Corey CG, Hoffman AC, et al. Symptoms of tobacco dependence among middle and high school tobacco users: results from the 2012 National Youth Tobacco Survey. Am J Prev Med 2014;47(Suppl 1):S4-14. https://doi.org/10.1016/j.amepre.2014.04.013

6. DiFranza JR, Savageau JA, Fletcher K, et al. Symptoms of tobacco dependence after brief intermittent use: the development and assessment of nicotine dependence in youth-2 study. Arch Pediatr Adolesc Med 2007;161:704-10. https://doi.org/10.1001/archpedi.161.7.704

7. US Department of Health and Human Services. Deeming tobacco products to be subject to the Federal Food, Drug, and Cosmetic Act, as amended by the Family Smoking Prevention and Tobacco Control Act. Final Rules. Fed Regist 2016 May 10. 81(90): 28974-29106. https:// www.gpo.gov/fdsys/pkg/FR-2016-05-10/pdf/2016-10685.pdf
8. US Department of Health and Human Services. The health consequences of smoking - 50 years of progress. a report of the Surgeon General. Rockville, MD: US Department of Health and Human Services; 2014. http://www.surgeongeneral.gov/library/reports/50-years-of-progress/fullreport.pdf

9. CDC. Best practices for comprehensive tobacco control programs-2014. Atlanta, GA: US Department of Health and Human Services, CDC; 2014. https://www.cdc.gov/tobacco/stateandcommunity/best_practices/ index.htm 